\title{
The optics of Jan van Eyck and Ibn al-Haytham
}

\section{Charles Falco, Aimée Weintz Allen}

Charles M Falco, Aimée L. Weintz Allen, "The optics of Jan van Eyck and Ibn al-Haytham," Proc. SPIE 8481, Optics Education and Outreach II, 84810L (15 October 2012); doi: 10.1117/12.929920

SPIE Event: SPIE Optical Engineering + Applications, 2012, San Diego, California, United States 


\title{
The optics of Jan van Eyck and Ibn al-Haytham
}

\author{
Charles M. Falco ${ }^{\mathrm{a}, \mathrm{b}}$ Aimée L. Weintz Allen ${ }^{\mathrm{a}}$ \\ ${ }^{\mathrm{a} O p t i c a l ~ S c i e n c e s ~ C e n t e r, ~}{ }^{\mathrm{b}}$ Department of Physics, University of Arizona, Tucson AZ 85721 \\ falco@u.arizona.edu
}

\begin{abstract}
Ibn al-Haytham (Latinized as Alhazen or Alhacen) wrote nearly one hundred works on topics as diverse as poetry and politics. With his landmark seven-volume Kitāb al-Manāzir [Book of Optics], published sometime between 1028 [418 A.H.] and 1038 [429 A.H.], he made intellectual contributions that subsequently were incorporated throughout the core of post-Medieval Western culture, including its optics and art. We have used material from both the writings of Ibn al-Haytham and the paintings of Jan van Eyck in a workshop teaching modern optical principles to a variety of audiences.
\end{abstract}

Keywords: image analysis, human vision, Renaissance, paintings, art, van Eyck, Holbein, Alhazen

\section{INTRODUCTION}

\subsection{Background}

Recently, the artist David Hockney reported visual discoveries within some of the best-known paintings of European art that affect long-held understandings of the development of Western art of the past 600 years[1]. Working in collaboration with him, one of us (CMF) then developed the foundations of a new methodology for extracting information from complex, optics-based images[2].

Briefly, we showed that certain features within very wellknown paintings (e.g. the chandelier in The Arnolfini Marriage by Jan van Eyck, as shown in Fig. 1) are based on optical projections. We determined that these optically-based elements of the paintings are

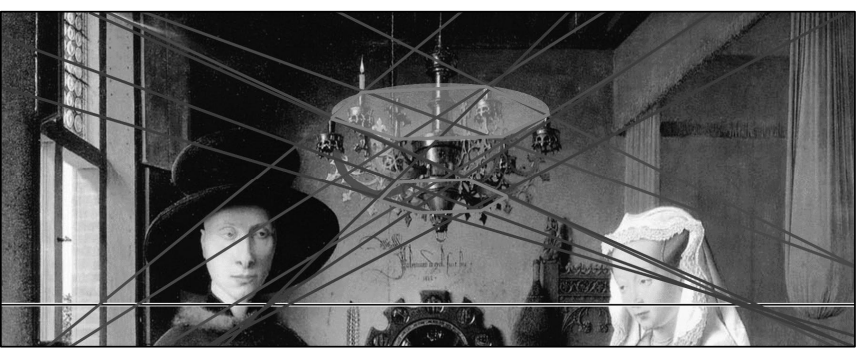
"photorepresentations"[3]. Our discoveries show that optical projections were being used by artists over 150 years before Galileo brought an optical instrument, the telescope, to wide attention.

\subsection{Human Vision and Image Analysis}

That the mind of a painter is as intrinsically involved in the creative process as his hand makes paintings intrinsically complex to analyze. Although tracing projected images is known to have become a common technique by the 19th century [1], earlier use of optics has been difficult to identify and analyze, hindered also by the lack of interaction between art historians and scientists. In spite of this difficulty, the painter David Hockney and one of us (CMF) recently identified optical evidence within a number of paintings demonstrating artists as early as Jan van Eyck (c1425) used optical projections as aids for producing portions of their images. While making these discoveries, fundamentally new insights into image analysis were developed that we are now applying to problems in computerized image display and analysis.

Although we only briefly address it in this paper, no less important for understanding the evolution of post-c1425 painting, as well as certain modern applications of image analysis, is the indirect use of optics. Unlike an image 
projected onto film, the human eye constantly adjusts its aim and focus as the mind constructs the scene it is viewing. As a consequence, humans do not simultaneously see part of a scene in focus and part out of focus. Hence, a simple example of the indirect use of optics is if an artist has painted a distant portion of a scene as if it were out of focus, replicating the depth-of-field of an image projected by a lens. Although modern humans have seen this effect countless times in the form of photographs, in movies, and on television, it is not an effect that is part of natural human vision.

\subsection{Ibn al-Haytham and the Psychology of Vision}

The fact that psychology is as intimately involved in vision as the simple geometrical optics of the eye occupies a significant part of Ibn al-Haytham's (Latinized as Alhazen or Alhacen) seven-volume treatise on optics [4, 5], the first time this topic was addressed in a modern scientific fashion. However, as discussed below, although he explained images of the crescent sun projected by a camera obscura in his treatise, "The Shape of the Eclipse," this optical device did not play a role in his understanding of vision.

\section{MEDIEVAL EUROPEAN OPTICS AND ART}

Briefly, both the theoretical knowledge of optics as well as the suitable optic elements - both refracting and reflecting were available by the early Renaissance. Sixty-one texts on optics written between the years 1000 , the time of alHaytham, and 1425, that of van Eyck, have survived, ${ }^{1}$ showing this 425 -year period was one of remarkable scientific activity. Although only a few of these texts have been translated from Latin, those that have provide detailed descriptions for fabricating suitable concave mirrors from metal. For example, "Make a spherical mirror as before [from clear iron]; smooth and polish its interior along the concave portion of its curvature...".[6]

Tomaso da Modena's 1352 paintings of Hugh of Provence and Cardinal Nicholas of Rouen show, respectively, spectacles and a magnifying glass, and Isnardo of Vicenza and St. Jerome both show concave mirrors. Not only were the necessary optics available by the early Renaissance, as shown by the da Modena paintings, they also were inexpensive.[7]

\subsection{Ibn Al-Haytham's Influence on European Optics}

The noted science historian, David Lindberg, wrote that "Alhazen was undoubtedly the most significant figure in the history of optics between antiquity and the seventeenth century"[5]. Impressive and accurate as this characterization of Ibn al-Haytham (Alhazen) is, it significantly understates the impact he had on areas as diverse as the theology, literature, art, and science of Europe.

Al-Haytham wrote nearly one hundred works, many of which have not survived, and today he is primarily known for his writings on geometrical optics, astronomy, and mathematics. However, it is with his landmark sevenvolume Kitāb al-Manāzir [Book of Optics], first published sometime between 1028 [418 A.H.] and 1038 [429 A.H.] that he made his most important contribution to the culture as well as the science of Medieval and Renaissance Europe.

\subsection{Historical Theories of Vision}

Al-Haytham's Kitāb al-Manāzir [Book of Optics] was

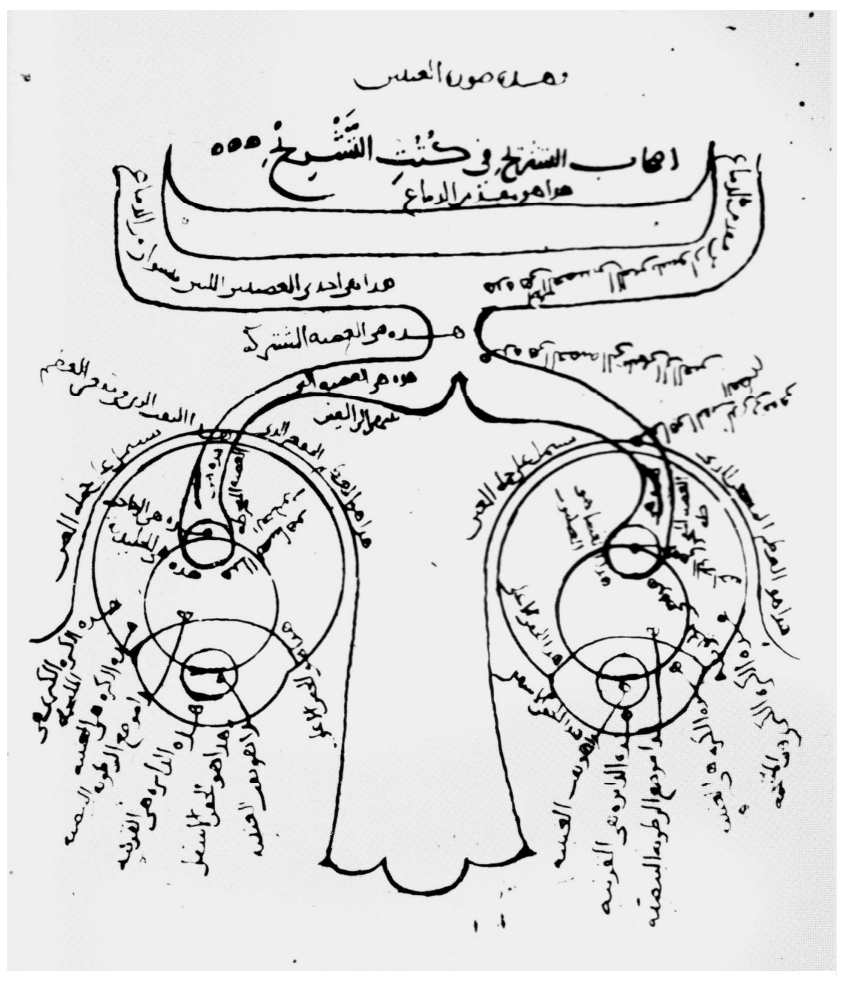

Figure 2. Ibn al-Haytham's description of the human visual system. From a 1083 [475 A.H.] copy of his Kitāb al-Manāzir in the Süleymaniye Library, Istanbul. 
translated into Latin in the early thirteenth century, and had a profound influence on European intellectuals, including figures as diverse as the writer Geoffrey Chaucer, the theologian John Wyclif, and the scientific work on optics of Bacon, Pecham, and Witelo. Al-Haytham's work was republished in Latin in 1572, after the advent of the printing press, and is explicitly referenced in the writings on optics by Kepler, Snell, and Fermat.

The genius of Ibn al-Haytham was not that he recognized there were problems with all existing theories of vision, since others before him had realized this as well. His genius lay in the fact that he found the solution that had eluded the best minds of antiquity. As mentioned previously, he recognized the crucial role of psychology (or how the mind interprets the world), and realized that to understand vision we must understand not only the geometrical optics of the eye, but also the psychological processes that interpret what the eye collects.

Al-Haytham did get one important aspect of vision wrong. The fact that an image projected by a lens is upside down and flipped right-to-left apparently was more than he could accept in a theory of vision, even though it is contained within his optical formalism. However, Leonardo da Vinci also failed to accept this when he approached the problem much later. Five hundred years later, Kepler directly followed al-Haytham's formalism to its inevitable and logical conclusion in developing the theory of the retinal image. The 1572 Latin translation of al-Haytham's, Opticae thesaurus: Alhazeni Arabis... is explicitly referenced in the writings on optics by Descartes and Fermat as well as Kepler.

\subsection{Medieval European Optical Scientists}

The Latin translation of the Kitāb al-Manāzir, 'De Aspectibus', translated sometime prior to the 1230s, and the proposals contained within it are used in the optics manuscripts Perspectiva by Roger Bacon (c1265), Perspectiva by Witelo (c1275), and Perspectiva communis by John Pecham (c1280). Although today we think of these scholars as optical scientists, they approached their work as theologians. In each case their interest in optics was motivated by their interest in vision, which in turn was motivated by religious belief. In essence, they hoped that developing an understanding of physical vision would provide them with insights into spiritual vision. Hence, the developments in geometrical optics that came from their studies were actually incidental to their religious drive to understand spiritual vision.

\section{Medieval European Theologians}

The $14^{\text {th }}$ century priest, John Wyclif, is credited with being the intellectual progenitor of the Reformation. Like his fellow priests of the time, Wyclif used optics in his theology. For example, he classified spiritual vision as direct, refracted, and reflected, and referred to alHaytham by name in discussing the seven deadly sins in terms of the distortions in the seven types of mirrors analyzed in 'De Aspectibus'. As shown in Fig. 4, Wyclif even used the Arabic word for parabolic mirror, mukephi, in his Latin text for 'De Eucharista', written in 1382.

\subsection{Renaissance European Art}

The Arab polymath Ibn al-Haytham not only had a direct influence on the development of European science, theology, and literature, but it can also be argued

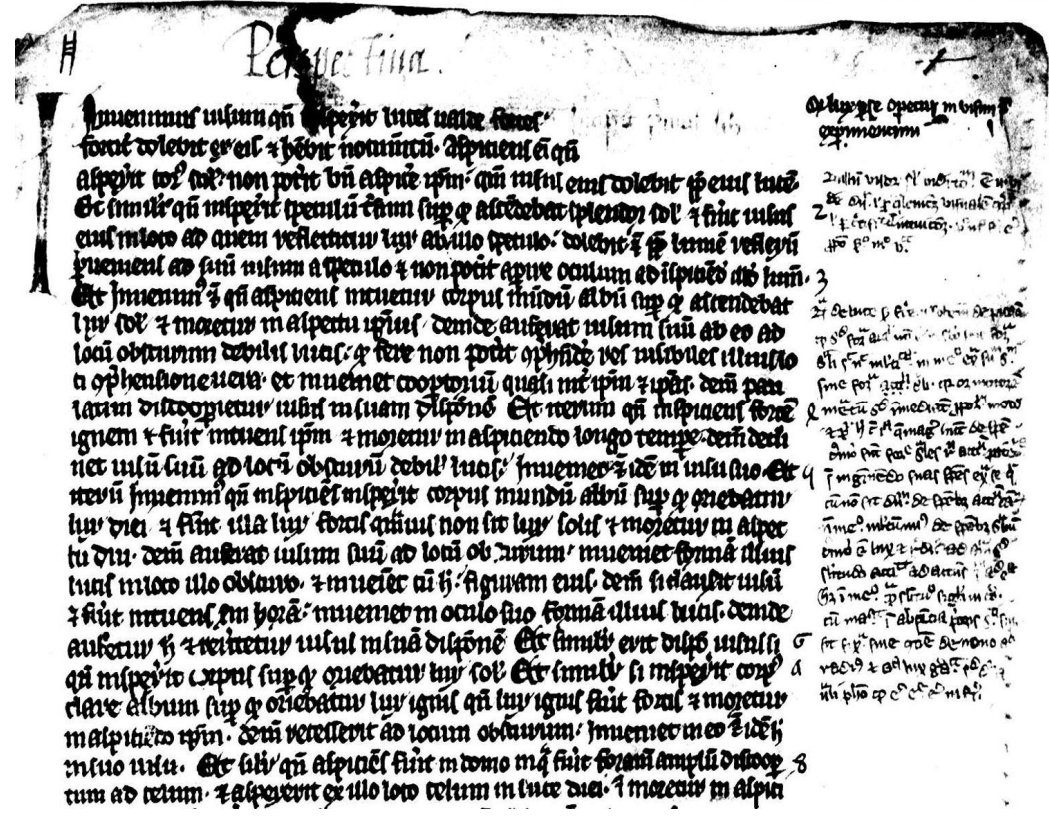

Figure 3. Excerpt from the first page of al-Haytham's Perspectiva, $14^{\text {th }}$ century (Sloane MS 306, fols 1-177, British Library, London). 
that he has had at least an indirect influence on art theory and art practice.

As Greenstein points out [8], Guerruccio di Cione Federighian translated al-Haytham into Italian in the 14th century, and portions of it were incorporated by Ghiberti in Book 3 of his Commentari. In this book, which was incomplete at the time of his death, Ghiberti attempted a theoretical understanding of the arts, relying heavily on optics.

Recent discoveries reveal al-Haytham's indirect influence on Western European art as well. The painter David Hockney in his book Secret Knowledge [1] made a range of observations about some of the best-known paintings of European art that affect longheld understandings of the emergence of realism at the dawn of the Renaissance. Building on these observations, Hockney and CMF developed the foundations of a new methodology for extracting information from complex, optics-based images. Briefly, we showed that certain features within very well-known paintings (e.g. the chandelier in The Arnolfini Marriage by Jan van Eyck) are based on optical projections. In addition to van Eyck (c1430), we found evidence of the use of optical projections within works by later artists, including Bermejo (c1475), Holbein (c1530), Caravaggio (c1600), de la Tour (c1650), Chardin (c1750) and Ingres (c1825). These examples demonstrate a continuum in the use of optics by artists from c1430, arguably initiated as a result of Ibn al-Haytham's influence, until today.

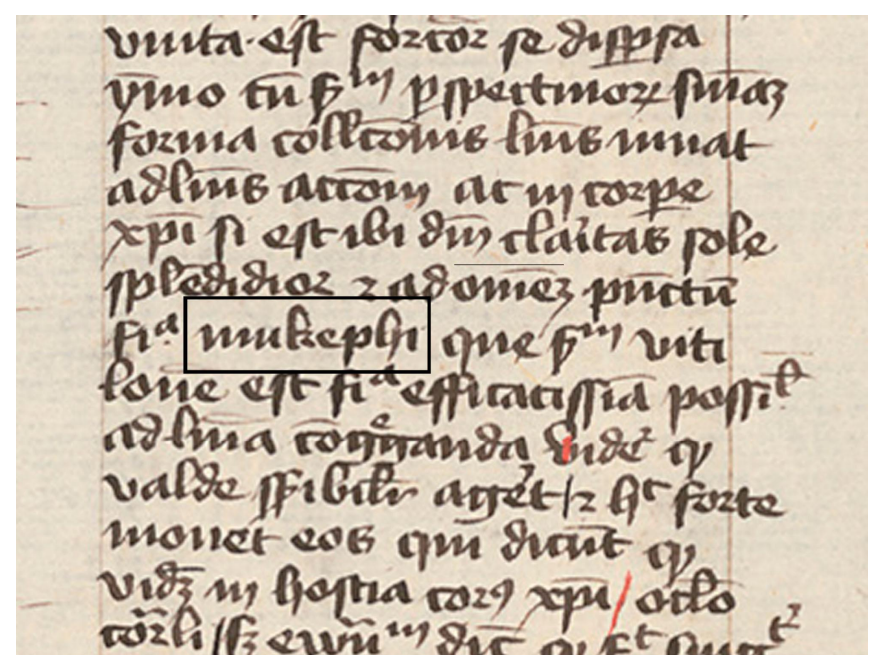

Figure 4. Excerpt from 'De Eucharistia' by John Wyclif, 1382, transcribed by Kourim of Bohemia in 1404-05, National Library of the Czech Republic. I have added a black box to highlight the Arabic word for parabolic mirror, 'mukephi'.

\section{ART AND OPTICS}

What influence perspectivist theories of vision had on the visual arts leading up to and throughout the Renaissance, however, has yet to reach a consensus among scholars. Writing on the influence of optical scientists on visual artists Klein states, "We may observe the widespread conviction that there was a close connection between their disciplines, really an identity."[9] He further states, "If one can believe Rafaello Maffei, the ancient science of Alhazen and Vitellio now included artistic applications and was almost identified with the fine arts." In the introduction of his English translation of De Aspectibus, Smith states: "The representation of visual space in Renaissance art was the expression of a world-view implicit in the Perspectivist analysis of sight, a world view based upon the 'geometrization' of visual space. If, however, Alhacen and his Perspectivist followers taught Renaissance artists to 'see' the world in such spatial terms, those artists in turn taught early modern thinkers to see the world in those same terms and thus to conceive of it as a Euclidean continuum."[4]

Written evidence of this "Euclidean continuum" is interpretable in the writings of such well known Renaissance masters as Alberti, Ghiberti and da Vinci, and equally important visual evidence is evident in the actual images created throughout the period. Alberti's most notable work, On Painting, c1435, for example, employs a model for vision taken directly from Ibn al-Haytham. Greenstein validates a parallelism between Ibn al-Haytham and Alberti's respective models of vision by stating, "Alberti's viewer first sees under aspects [aspecimus]; then recognizes by intuition [intuentes...dignoscimus]; and finally discerns with greater discrimination [aspicientes distinctius...discernimus]."[8]

Given the progression of events it seems unusual that an artist like Alberti was so familiar with the perspectivist tradition, and yet so little is known about how he arrived at the principles of linear perspective. Nevertheless, a clear language of visual literacy has been established, beginning most significantly with the work of Ibn al-Haytham and culminating with Alberti's visual pyramid for artistic production during the Renaissance. 


\section{WORKSHOP ON THE OPTICS OF IBN AL-HAYTHAM}

Recently we developed a half-day workshop to teach fundamental principles of optics based on optical principles articulated by Ibn al-Haytham and used by Jan van Eyck. The premise behind this is that interest in these scholars and their work would provide significant motivation to learn aspects of optics. All of the necessary equipment for this workshop fits into a case designed for shipping a set of golf clubs as checked baggage, and the syllabus covers the following:

- Review the life and work of Ibn al-Haytham; the 'new' knowledge he produced and the influence his work has had over centuries.

- Use experiments taken directly from al-Haytham's Kitab al-Manazir, to teach optical concepts including:

- $\quad$ light travels in straight lines (3-bulb apparatus; color reflects in the same way as light;

- reflected light and color are weaker than the original light and color producing them;

- the bigger the aperture opening, the brighter the image;

- the smaller the aperture opening, the larger the depth of field; but the dimmer the image;

- the farther light extends from its source, the weaker it gets because of both 'distance' and 'dispersal' and the act of 'reflection,' and it is strengthened by 'concentration';

- light spreads out 'conically' - the narrower the beam of light striking the mirror, the less it spreads out in the course of radiation and reflection;

- images projected by a pinhole are inverted and reversed;

- images projected by lenses are inverted and reversed;

- images projected by concave mirrors are inverted but maintain the parity of the image;

- Use the camera obscura to introduce and validate the $M=\frac{h_{i}}{h_{0}}=-\frac{d_{i}}{d_{0}} \quad \frac{1}{f}=\frac{1}{d_{0}}+\frac{1}{d_{i}} \quad$ equations for magnification and focal length;

- Demonstrate why al-Haytham's work is useful for artists (camera obscura and reflex camera obscura for tracing images) by providing art materials and having teachers create portraits of each other;

- Review specific 'project-based' assignments that can be given to students as a means for solving specific problems either in class, or at home (hand-outs provided), including: constructing cameras obscura and pinhole cameras; producing projected images based on specific levels of magnification and focal lengths; producing portraits based on these same requirements, etc.

We have presented this workshop to various groups in Saudi Arabia, the U.S., and the U.A.E., and evaluation questionnaires filled out by participants indicate it was quite successful in conveying key optical concepts. 


\section{SUMMARY AND CONCLUSIONS}

As a consequence of the way they were constructed, the optics-based paintings discussed here are much more complex than photographs. However, in spite of this complexity, we were able to extract quantitative evidence from these images, even though they were produced by hand and contain both optics-based and non-optics-based ("eyeballed") features. These discoveries demonstrate that highly influential artists used optical projections as aids for producing some of their paintings early in the $15^{\text {th }}$ century, at the dawn of the Renaissance, at least 150 years earlier than previously thought possible. In addition to van Eyck, Campin and Holbein, we also have found optical evidence within works by later artists, including Bermejo (c1475), Caravaggio (c1600), de la Tour (c1650), Chardin (c1750) and Ingres (c1825), demonstrating a continuum in the use of optics by artists, along with an evolution in the sophistication of that use.[1] However, even for paintings where we have been able to extract unambiguous, quantitative evidence of the direct use of optical projections for producing certain of the features, it does not mean that these paintings are effectively photographs. Because the hand and mind of the artist are intimately involved in the creation process, understanding these images requires more than can be obtained from only applying the equations of geometrical optics. Also, although we have only briefly addressed it in this manuscript, no less important for understanding the evolution of post-c1425 painting is the indirect use of optics.[1]

\section{ACKNOWLEDGEMENTS}

We are pleased to acknowledge valuable contributions by David Graves, Ultan Guilfoyle, David Hockney, Martin Kemp, Nora Roberts (neé Pawlaczyk), José Sasián, Richard Schmidt, and Lawrence Weschler.

\section{REFERENCES}

[1] Hockney, David (2001, 2006). Secret knowledge: Rediscovering the lost techniques of the old masters. Thames and Hudson (2001), Penguin Group (2006).

[2] Hockney, David and Falco, Charles M. (2005). Proceeding of IS\&T-SPIE Electronic Imaging: Quantitative analysis of qualitative images, SPIE, 5666, p. 326.

[3] Hockney, David and Falco, Charles M. (2005). Proceedings of Photonics Asia: Optical instruments and imaging: the use of optics by $15^{\text {th }}$ century master painters. SPIE, 5638, p. 1 .

[4] Smith, Mark A. (2001). Alhacen's theory of visual perception: A critical edition, with English Translation and Commentary, of the First Three Books of Alhacen's "De Aspectibus," the Medieval Latin Version of Ibn al-Haytham's "Kitāb al-Manāzirir": Volume One, Transactions of the American Philosophical Society, New Series, 91 (4). American Philosophical Society

[5] Lindberg, David C. (1967, Autumn). Alhazen's theory of vision and its reception in the West, Isis, 58 (3), 321-341.

[6] A.M. Smith, translator, Book V of Witelo's Perspectiva [c1274] (Polish Academy of Sciences, 1983), p. 98.

[7] Vincent Ilardi, Renaissance Vision, from Spectacles to Telescopes (American Philosophical Society, 2005).

[8] Greenstein, Jack M., (1997, December). On Alberti's "sign": Vision and composition in quattrocento painting, The Art Bulletin, 79 (4), 669-698. Quote found on pg. 682.

[9] Klein, Robert (1961, September). Pomponius Gauricus on perspective, The Art Bulletin, 43(3), 211-230. College Art Association. 